\section{Viral Nervous Necrosis in Hump- back Grouper Cromileptes altivelis Larvae and Juveniles in Indonesia}

\author{
Zafran $^{1}$, Isti Koesharyani ${ }^{1}$, Fris Johnny ${ }^{1}$, \\ Kei Yuasa ${ }^{2}$, Takahiko Harada ${ }^{3}$ \\ and Kishio Hatai ${ }^{4 *}$ \\ ${ }^{1}$ Gondol Research Station for Coastal Fisheries, P. O. Box \\ 140, Singaraja 81101, Indonesia \\ 2 Japan International Cooperation Agency, Shinjuku Maynds \\ Tower Bldg. 11 th floor, 2-1-1 Yoyogi, Shibuya, \\ Tokyo 151-8558, Japan \\ ${ }^{3}$ Division of Biology, Faculty of Veterinary, Nippon Veteri- \\ nary and Animal Science University, Kyonan-cho \\ 1-7-1, Musashino, Tokyo 180-8602, Japan \\ ${ }^{4}$ Division of Fish Diseases, Faculty of Veterinary, Nippon \\ Veterinary and Animal Science University, Kyonan-cho \\ 1-7-1, Musashino, Tokyo 180-8602, Japan
}

(Received February 14, 2000)

Key words: viral nervous necrosis, nodavirus, Cromileptes altivelis, Indonesia, VNN

One of the main activities at the Gondol Research Station for Coastal Fisheries (GRSCF), Bali, Indonesia is to disseminate the skills for the reproduction and growth of humpback grouper to private hatcheries in Indonesia, which is conducted under the Indonesia/Japan technical cooperation project. Since 1998, several private hatcheries in Bali and east Java have attempted to produce juveniles of humpback grouper. However, in November 1998, mass mortality of larvae and juveniles of humpback grouper occurred at a hatchery near the Station. The present paper describes the cause of the mortality that occurred at that time.

\section{Materials and Methods}

Eggs of the humpback grouper used in the hatchery at which the mortality occurred were obtained from broodstock rearing at GRSCF. Ten and 30-day-old larvae and 52-day-old juveniles were being reared in 10-ton concrete tanks at the hatchery, when mass mortality started in the 52-day-old juveniles. The mortality rose to $85 \%$ in a week. Two days after the initial mortality, moribund fish were observed in other two tanks, and the cumulative mortality in each tank reached $100 \%$ within 3

\footnotetext{
* Corresponding author

E-mail: hatai@scan-net.ne.jp
}

days. Sluggish behavior near the water surface and resting on the bottom were characteristically observed in the affected fish in each tank. The water temperature when the mortality occurred was $26-28^{\circ} \mathrm{C}$.

Thirty-day-old larvae and 52-day-old juveniles were examined as follows. The moribund fish were fixed in $10 \%$ phosphate buffered formalin for histopathological examination or stored in a $-85^{\circ} \mathrm{C}$ freezer for later $\mathrm{PCR}$ examination. The gills and body surface were examined microscopically for parasites. Bacterial isolation from the liver was attempted at $27^{\circ} \mathrm{C}$ using Brain Heart Infusion Agar, Marine Agar and Thiosulphate Citrate Bile Salt Sucrose Agar, and incubated. Formalin-fixed samples were embedded in paraffin wax and the sections were stained with haematoxylin-eosin (H\&E). For transmission electron microscopy for observation of viral particles, some samples were refixed in a $2.5 \%$ glutaraldehyde-2\% para-formaldehyde mixture $(\mathrm{pH} 7.4)$, then post-fixed with $1 \%$ osmium tetroxide, and embedded in Quetol 812. Thin sections were stained with $1 \%$ uranyl acetate and $1 \%$ lead citrate, and then examined with an electron microscope.

Histopathological and other evidence (described below) raised the possibility that piscine nodavirus (causative agent of viral nervous necrosis) might be present. To determine whether this virus was present, PCR was used to detect the nodavirus coat protein gene (RNA2). The target sequence was a 426-bp sequence referred to as $\mathrm{T} 4^{1)}$. RNA was extracted and amplified as described by Mushiake et al. ${ }^{2)}$

For an experimental infection, a viral filtrate was prepared as described by Mori et al. ${ }^{3)}$ Then 10 normal 2month-old humpback grouper juveniles $(25$ to $30 \mathrm{~mm}$ in total length) were placed in a bath and challenged with the filtrate. Each 10 fish was kept in two $30-\mathrm{L}$ tanks with and without the $0.3 \mathrm{~mL}$ viral filtrate at 26 to $27^{\circ} \mathrm{C}$ for 2 weeks. All samples used in the experiments were examined histopathologically and the presence of nodavirus in 10 eyes pooled from 10 fish was determined by PCR.

\section{Results and Discussion}

Neither parasites nor bacteria were isolated from the samples. Histopathological examinations showed vacuolation and degeneration of nerve cells in the brains and retinas of all examined fish. Electron microscopy revealed numerous round-shaped viral particles, approximately 25 to $30 \mathrm{~nm}$ in diameter, in the cytoplasm of the degenerated nerve cells in the brain and retina. The target sequence T4 (426 bp) was amplified by PCR from the sample prepared from one eye in each 5 fish (Fig. 1).

The affected fish that were examined showed abnormal behaviors: twirling swimming or resting on the bottom, after 4-7 days, but no mortality occurred during the 


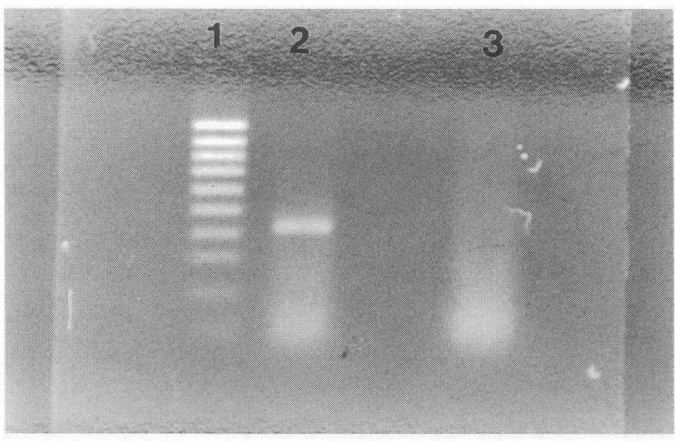

Fig. 1. Detection of SJNNV gene from juvenile humpback grouper by PCR amplification. Lanes: 1, DNA ladder; 2 , amplified product from total nucleic acids extracted from five moribund 52-day-old juveniles; 3 , amplified product from five normal humpback grouper juveniles.
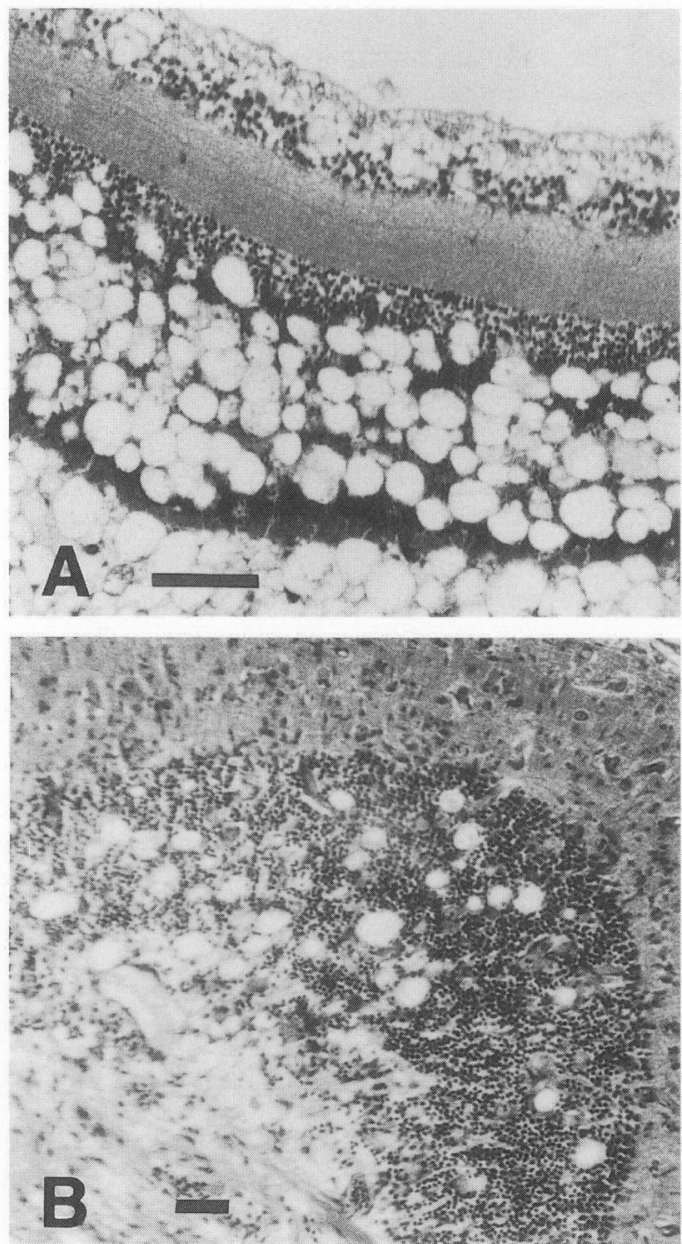

Fig. 2. Light microscopy showing vacuolation in the retina (A) and the brain (B) of a humpback grouper juvenile experimentally infected with the filtrate made from moribund 52-day-old juveniles (H \& E). Bars $=50 \mu \mathrm{m}$. experimental period. Vacuolation and degeneration of nerve cells in the brains and retinas were histopathologically observed in all of the infected 10 fish after two weeks (Fig. 2, A and B), but not in the control fish. PCR-positive reaction was detected only in the two samples, which were pooled from each 5 in 10 fish that had been challenged with the viral filtrate.

Based on the histopathological features in the eyes and brain of the diseased fish, the morphology of the detected virus and positive result of PCR in detecting the SJNNV gene, the mass mortality in humpback grouper could be diagnosed as viral nervous necrosis (VNN).

Several grouper species have been reported to be hosts of piscine nodaviruses ${ }^{4)}$, and the sizes that are affected range from larvae to immature fish ${ }^{3,5}$. In the present study, mortality in humpback grouper were observed among 12, 32 and 52-day-old fish: 12- and 32day-old larvae showed $100 \%$ mortality, but some juveniles in the oldest group could tolerate the infection. In the challenge experiment, the fish exposed to the viral filtrate showed the characteristic symptoms of VNN, but did not die. Thus, the sensitivity of the fish to the virus may depend on the age of the fish. Further studies of the pathogenicity of the virus to fish in different stages are needed.

Recently the occurrence of the disease in seabass larvae and juveniles was reported in Indonesia ${ }^{6)}$. Measures to control the disease should be required in seed production of mariculture fish in Indonesia.

\section{Acknowledgement}

This research was conducted under the technical cooperation project implemented by the Japan International Cooperation Agency (JICA) to Gondol Research Station for Coastal Fisheries, Central Research Institute for Fisheries, Indonesia.

\section{References}

1) Nishizawa, T., K. Mori, T. Nakai, I. Furusawa and K. Muroga (1994): Dis. Aquat. Org., 18, 103-107. 2) Mushiake, K., T. Nishizawa, T. Nakai, I. Firusawa and K. Muroga (1994): Fish Pathol., 29, 177-182. 3) Mori, K., T. Nakai, M. Nagahara, K. Muroga, T. Mekuchi and T. Kanno (1991): Fish Pathol., 26, 209-210. 4) Munday, B. L. and T. Nakai (1997): World J. Microbiol. Biotechnol., 13, 375-381. 5) Fukuda, Y., H. D. Nguyen, M. Furuhashi and T. Nakai (1996): Fish Pathol., 31,165-170. 6) Zafran, T. Harada, I. Koesharyani, K. Yuasa and K. Hatai (1998): Indonesian Fisheries Research Journal, 5, 19-22. 